\title{
UN RETRATO FAMILIAR DE LOS ACOSTA EN SU SEGUNDA FASE SEVILLANA
}

\author{
POR Alfonso Pleguezuelo HeRnández
}

Partiendo de una frase de Ceán Bermúdez, este rabajo, de base documental, pretende reconstruir el contexto familiar de Cayetano de Acosta, escultor y retablista portugués afincado en Sevilla. El interés de estos datos familiares reside en que sus hijos formarón el taller en que se ejecutaron algunas de las obras más importantes de nuestro barroco tardío sevillano. Los movimientos de la familia dentro y fuera de la ciudad, las compras de casas y corrales, la reconstrucción del diagrama familiar, la distinción entre sus dos hijos homónimos llamados Francisco, la diferenciación entre sus supuestos estilos, rococó uno, neoclásico el otro, o el vínculo con el escultor genovés Juan Bautista Parrone casado con una nieta de Cayetano, son algunas de las hipótesis e informaciones aquí expuestas por vez primera. Al hilo de estos datos familiares se sugieren algunas nuevas atribuciones apoyadas en análisis estilísticos.

The aim of this docummentary study, based on a commentary of Céan Bermúdez, is to reconstruct the domestic world of Cayetano de Acosta, the Portuguese sculptor and altarbuilder established in Sevilla. The interest of this information lays in the fact that his sons formed the domestic workshop where some of the most important works of our late Sevillian barroque period were created. Some of the facts and working hypothesis, first displayed in this study are the following: the family changes of address in and out of the city; the purchases of houses and courtyards; a study of the family tree; a correct identification of his two homonymous sons called "Francisco"; a distinction between their alleged styles, Rococo, one of them, and Neoclassic, the other; or the links to the Genoese sculptor Juan Bautista Patrone, married to a granddaughter of Cayetano de Acosta. The aforementioned family details and certain data obtained after a stylistic analisis allow us to suggest the authorship of some new works.

"Falleció este artista en Sevilla el año de 1780; pero dexó vinculados sus despropósitos a su hijo, nieto y discípulos, que procuran observarlos exactamente"

(Ceán Bermúdez, 1800)

Con esta irónica y cruel -además de inexacta- frase necrológica, termina Ceán el despiadado comentario que dedica al escultor y arquitecto de retablos Cayetano de Acosta ${ }^{1}$

1. CEÁN BERMÚDEZ, Juan Agustín: Diccionario Histórico de los más ilustres Profesores de Bellas Artes en España, (Madrid, 1800), pág. 4. 
Con independencia de cuáles fueron sus discípulos -asunto que habría que indagar por un camino distinto del que aquí se ha emprendido- el párrafo nos crea la incógnita acerca de quiénes pudieron ser el hijo y el nieto en los que Cayetano halló los mejores oficiales de su taller familiar y que serían después algunos de los más fieles continuadores de sus sorprendentes "despropósitos".

La búsqueda de estos dos personajes, nombrados de forma anónima por Ceán, ha conducido a esbozar documentalmente un "retrato de familia" en el que aparecen como posibles continuadores de Cayetano algunos más de los dos descendientes citados. La crítica posterior deberá aquilatar la importancia real de estos escultores y ensambladores de la segunda mitad del siglo XVIII de los que aquí sólo daremos sus nombres y cuya obra apenas será citada en este trabajo, que sólo pretende plantear con una base documental el hasta ahora desconocido árbol genealógico de los descendientes de este artista sevillano de adopción.

Sin tomar en cuenta su nacimiento en Lisboa y los años de su infancia portuguesa, de la que nada sabemos, su vida familiar y profesional atravesó sucesivamente tres fases en relación a sus lugares de resídencia: Sevilla, Cádiz y, de nuevo, Sevilla.

De su primera etapa sevillana, que empezó con anterioridad a 1729 y debió terminar hacia 1738, año en que ya lo encontramos trabajando en Cádiz, nada hemos hallado a excepción de su matrimonio ${ }^{2}$ y del nacimiento de sus hijos Juan, Antonia y Francisco de Asís ${ }^{3}$.

Sin embargo, la fase gaditana ha resultado ser, por lo que sabemos hasta ahora, tan fecunda desde el punto de vista familiar como desde el artístico. En el primer aspecto, nacieron allí cinco hijos y, respecto del segundo, se han podido documentar y atribuir unas cuantas obras de talla en piedra realizadas fundamentalmente para la Nueva Catedral. Pero es poca producción para los doce años de su estancia gaditana. Con toda seguridad, irán apareciendo más obras de Acosta y sus hijos en Cádiz y su entorno. Informaciones sobre aquella fase ya se dieron a conocer en algún trabajo anterior ${ }^{4}$.

2. PLEGUEZUELO HERNÁNDEZ, Alfonso: Aportaciones a la biografía y obra de Cayetano de Acosta: la fase gaditana, "Boletín del Seminario de Estudios de Arte y Arqueología", Tomo LIV, (Valladolid, 1988), pag. 498.

3. Aunque no hemos encontrado las partidas bautismales de estos tres hijos de Acosta, su lugar de nacimiento se conoce por las de matrimonio que se incluyen al final de este artículo y en las que se declaran naturales de esta ciudad. Aparte de estos tres nacimientos, la única referencia que tenemos de esta etapa sevillana es un párrafo de Cuellar en que comenta de pasada haber hallado un documento que denuncia la presencia de Acosta en Sevilla en 1736. No sabemos a qué acontecimiento puede referirse esta noticia. Cfr. CUELLAR CONTERAS, Francisco de P.: Los retablos colaterales de la iglesia del Sagrario de Sevilla, "Atrio" $\mathrm{n}^{\circ} 4$ (Sevilla, 1992), pag. 104.

4. Véase PLEGUEZUELO HERNÁNDEZ, Alfonso: Aportaciones.... Para la obra gaditana de Acosta debe también consultarse el trabajo de MARTíNEZ MONTIEL, Luis: Una escultura de Cayetano de Acosta en el convento del Carmen de San Fermando (Cádiz), "Laboratorio de Arte" no 4 (Sevilla, 1991), pags. 329-333. 
Tras finalizar su período gaditano, Acosta llega de nuevo a Sevilla entre el 24 de julio y el 3 de agosto de $1750^{5}$. En el momento de regresar ${ }^{6}$, tenía ya tres hijos y cuatro hijas: Juan, Antonia y Francisco de Asís, nacidos en Sevilla, y Francisco Antonio, María, Agustina y Andrea, estos últimos nacidos en Cádiz. ${ }^{7}$

Desde 1750 a 1757 es probable que la familia Acosta residiera por razones de comodidad, cerca de la Catedral y de la Real Fábrica de Tabacos, edificio este último donde Cayetano y sus hijos mayores trabajarían de forma cotidiana ${ }^{8}$. Durante tal período fueron parroquianos del Sagrario, templo donde el 3 de agosto de 1751 se bautiza el menor de sus hijos, segundo de los llamados Andrés (Ap. Doc. $n^{\circ} 1$ ), nacido al poco tiempo de llegar a Sevilla. También en esa parroquia se casa su hija mayor Antonia de Acosta en mayo de 1755 , como veremos más adelante.

Aunque su labor en la Fábrica de Tabacos debió acaparar la mayor parte de su tiempo, también se ejecuta por entonces en su taller alguna importante obra de madera. Concretamente, el retablo principal de la capilla de San José del gremio de carpinteros, que debió proyectarlo Acosta hacia el año $1757^{9}$.

5. La última referencia documental de la presencia de Acosta en Cádiz y la primera en su posterior etapa sevillana fueron dadas a conocer en nuestro citado trabajo Aportaciones ..., pag. 496.

6. Hasta hace poco pensábamos que el regreso a Sevilla estaba justificado por su incorporación como tallista a la obra de la Real Fábrica de Tabacos. Después del trabajo de Cuellar Contreras citado en la nota 3, en el que documenta como obras suyas las esculturas de los retablos marmóreos laterales del Sagrario de la Catedral, es preciso pensar que fue más bien este temprano y espléndido conjunto de seis imágenes de mármol blanco y dos de madera policromada el que motivó el regreso de Cayetano a Sevilla. De hecho, firma el contrato para estas esculturas en diciembre de 1749 cuando todavía residía y trabajaba en Cádiz (CUELLAR CONTRERAS, Francisco de P.: ob. cit., pag. 104).

7. No contamos en este elenco a su hijo Andrés Cayetano, nacido en Cádiz en 3 de abril de 1747. Debió fallecer muy pronto.

8. La última referencia que se tiene del trabajo de Acosta para la Real Fábrica data del 10 de marzo de 1758 en que se comenta que ha terminado de tallar los "cuatro remates principales de las esquinas de esta real obra, los 8 que están junto a la Fama de la portada y las dos fuentes de los patios grandes". Cfr. CARRERA SANABRIA, Manuel: Unas obras desconocidas del Escultor Cayetano de Acosta, "Archivo Hispalense", Tomo V, (Sevilla, 1945) pag. 28. Para la obra de Cayetano de Acosta en la Real Fábrica de Tabacos puede consultarse del mismo autor Más sobre Cayetano de Acosta y sus obras en la Fábrica de Tabacos de Sevilla "Archivo Hispalense", Tomo VIII, (Sevilla, 1945), pags. 293-396. Algunas puntualizaciones sobre la intervención de Acosta en este conjunto pueden leerse también en PLEGUEZUELO HERNÁNDEZ, Alfonso: Sobre Cayetano de Acosta. escultor en piedra, "Revista de Arte Sevillano", $n^{\circ} 2$ (Sevilla, 1982), pags. 35-42.

9. En cabildo de 16 de enero de ese año se decide tratar el tema del retablo con Julián Ximenez: "para que diga en el tanto que se determina a ejecutar el retablo del altar mayor según dibujo que tiene hecho...". (Archivo de la Capilla de San José. Libro de Acuerdos de Cabildo de la Hermandad del Señor San Joseph", sin fol.). Es curiosa y a la vez extraña esta noticia que vincula el retablo, tradicionalmente atribuido a Cayetano de Acosta, a su discípulo más importante. Es probable que el proyecto fuese de Acosta y la ejecución, de Jiménez. La documentación vuelve sobre el asunto varios años más tarde presentando de nuevo a Jiménez como ejecutor del retablo. No obstante, el estilo de la obra coincide plenamente con la forma de hacer del maestro y no con la conocida hasta ahora de su discípulo. Recientemente Hernera ha publicado unos datos de gran interes relacionados con esta obra pero que enturbian aún más la autoría de su diseño, ya que da a conocer la noticia de que el pintor Federico del Pozo hizo un diseño para esta obra por esas mismas fechas y con características que recuendan al ejecutado finalmente. Cfr. Francisco J. HERRERA GARCÍA: Sobre la intromisión de otras artes en la arquitectura. Un ejemplo sevillano, "Atrio" n 4, 1992, p. 123 y ss. 
No sería de extrañar que también fuera de su mano, además de los escudos heráldicos tallados en piedra que en otro lugar ya le hemos atribuido ${ }^{10}$, el que se colocó en la esquina del Palacio de los Pumarejo en la plaza sevillana de dicho nombre. El escudo, coronado con un yelmo y penacho de plumas, posee una composición simétrica y se rodea de rocallas y ces de una suculencia que sólo Acosta sabía dar a la decoración (Lám. 1). Se apoya por debajo en una expresiva cabeza de turco con rasgos de sátiro y a los lados aparecen armas y trofeos militares. Podría ser obra de la década de los cincuenta.

Terminada su tarea en la monumental Real Fábrica, Cayetano, en compañía de su mujer y de sus hijos solteros, se muda a la collación de San Martín, a una casa en la calle de la Tinaja que compra en 1758 a los herederos de Marco Sancho ${ }^{11}$ (Ap. Doc. $n^{\circ}$ 2). En este domicilio vivió la familia Acosta hasta $1792{ }^{12}$.

Al tiempo que compra la casa, adquiere también a los herederos del citado personaje, dos corrales de vecinos situados en esa zona: uno pequeño en la calle Cañaverería (hoy Joaquín Costa) y otro grande al final de la Alameda, en la Cruz del Rodeo (hoy Plaza de la Niña de los Peines) (Fig. 1) ${ }^{13}$. Con estas adquisiciones, el escultor tendría su casa y su taller en edificios distintos pero muy cercanos, lo que comportaría muchas ventajas. Por otro lado, la compra en efectivo de estos inmuebles nos indica que Acosta por esas fechas, gozaba, a pesar de su gran carga familiar, de una holgada situación económica.

Por fortuna, se ha podido controlar documentalmente la presencia y ausencia de casi todos los miembros de la familia en la casa de la calle de la Tinaja y en sus alrededores con una frecuencia anual, gracias a que se han conservado los

10. PLEGUEZUELO HERNÁNDEZ, Alfonso: Sobre Cayetano de Acosta. escultor en piedra, "Revista de Arte sevillano" $n^{\circ} 2$ (Sevilla, 198 ), pag. 38.

11. Este personaje fue un conocido Maestro Mayor de obras de la ciudad de Sevilla que trabajó durante el primer tercio del siglo XVIII. Á partir de 1775 la calle se llamó "de Marco Sancho". No obstante, resulta extraño que en el padrón parroquial, el nombre de "Tinaja" se sustituya por el de "Marco Sancho" casi veinte años después del fallecimiento del personaje. En el plano de ciudad hecho por mandato del Asistente Olavide en 1771 aparece situada erróneamente y rotulada como calle Martín Sánchez.

12. Debido al proceso de concentración parcelaria de esa zona durante el siglo XIX, no hemos podido identificar el solar indicado a partir de las medidas que se ofrecen en el documento notarial aunque sí sabemos con seguridad la manzana en que estuvo situado. El nuevo domicilio se describe en el protocolo de compraventa como compuesto por dos casas unidas que forman una parcela de cuatro varas y media de fachada hacia la calle de la Tinaja (hoy Marco Sancho) y dieciocho y media a la trasera calle del Pepino (hoy Santa Rufina).

13. Es probable que en alguno de esos corrales montara Acosta sus talleres de escultura y ensamblaje puesto que ese tipo de edificación suele ser, por su amplio espacio y su estructura arquitectónica, muy apto para tal fin, como lo demuestra el hecho de que aún hoy los usan artesanos de este ramo en Sevilla. 
padrones parroquiales en que aparecen citados de forma sistemática desde 1759 en adelante ${ }^{14}$.

En ese año aparecen ya como habitantes del inmueble Cayetano de Acosta, su mujer Isabel de Amil ${ }^{15}$ y sus hijos Francisco de Asís ${ }^{16}$, Francisco Antonio, María, Agustina y Andrea.

Es lógico que no aparezca ya Juan de Acosta, el primogénito, independizado desde 1753, año en que había contraído matrimonio con María Carballo (Ap. Doc. $n^{\circ} 3$ ). Tampoco podía vivir entonces con sus padres Antonia, ya que en mayo de 1755 se había casado con Antonio Moreno (Ap. Doc. $\left.n^{\circ} 4\right)^{17}$. No figura tampoco el pequeño Andrés, que en este momento contaba con ocho años de edad, aunque aparecerá registrado dos años más tarde ${ }^{18}$.

Francisco de Asís, el segundo varón, sólo vive en este nuevo domicilio familiar el primer año ya que se casa con Felipa de Cáceres probablemente en 1760. Después de trece años viviendo en alguna calle de San Martín que desconocemos, aparecerá como vecino de otra de la misma collación; la calle Cañaverería, muy cerca de la de la Tinaja. Poco después de casarse emprendería con su padre y sus hermanos el conjunto de retablos y esculturas de la iglesia del

14. Por las enormes facilidades prestadas en la consulta documental, queremos expresar aquí nuestro sincero agradecimiento a Don Juan Talavera, cura párroco de la iglesia de San Andrés donde se custodia también el Archivo de la vecina parroquia de San Martín. Advertimos al lector desde ahora que no citaremos esta fuente cada vez que usemos los datos del Padrón de esta última parroquia no sólo por no ser reiterativos, sino también porque se trata de cuadernillos formados por hojas sin foliar cuyo único sistema de referencia son los años y éstos ya van citados en el texto.

15. Transcribimos el apellido de la mujer de Acosta como "de Amil" a pesar de que con cierta frecuencia aparece en los documentos como "de Amir" y también su forma contraída "Damil". No deben extrañar estos cambios, ya que las terminaciones en " 1 " $y$ en " $r$ " se confunden frecuentemente en ciertos enclaves lingüísticos andaluces. Nada sabemos de la familia "Amil". Parece que vivían en Triana, collación donde se casa la pareja y donde años después siguen viviendo, al igual que en el Sagrario, algunos feligreses de dicho apellido que aparecen a veces apadrinando a nietos de Acosta.

16. De esta forma se nombra a uno de los dos en 1762. Dado que conocemos el nombre completo del más joven de ellos por su acta de bautismo, en la que se le nombra Francisco Antonio, deducimos que Francisco de Asís debe ser el mayor de los dos quien, además, bautizará a su primogénito con ese mismo nombre compuesto.

17. Hay un error al asentar la partida y quien lo hizo equivocó probablemente el lugar de nacimiento de la contrayente citando la Puebla de Cazalla (Sevilla) y el apellido de su padre, a quien llama Cayetano "Barbudo" en lugar de Cayetano de Acosta. Se trata de un error evidente, ya que todos los demás datos personales coinciden con la hija del artista. Por otro documento posterior sabemos que en 1779 seguía aún casada con Antonio Moreno. Por la coincidencia de apellido, es probable que su marido tuviese algún vínculo familiar con Andrés Moreno, vecino del Sagrario que aparece como padrino de bautismo de tres hijos de Acosta a los que dan ese mismo nombre de forma insistente; Andrés Cayetano y Andrea, bautizados ambos en Cádiz, y Andrés Santa Ana, nacido ya en Sevilla. Fuera quien fuese, debió tener una relación muy estrecha con Acosta, quizás por vía de su mujer, ya que Andrés Moreno era marido de una tal María de Amil, que será madrina en 1770 de un nieto de Cayetano.

18. Probablemente no lo anotan por su temprana edad, ya que solían incluir en el padrón de feligreses sólo a los que habían realizado la Primera Comunión. 
convento de Santa Rosalía, ejecutados entre 1761 y 1762 y financiado personalmente por el Arzobispo de Sevilla el Cardenal Solís, de quien Cayetano de Acosta fue escultor de confianza.

Es muy probable que durante esta década Cayetano reformara el retablo de la Capilla de la Hermandad de los Servitas, obra que no se ha vinculado nunca a su labor y que nosotros ahora le atribuimos (Lám. 2). Se trata de la reforma de un antiguo retablo de orden salomónico realizado hacia 1700. De él se aprovechan el banco, las calles laterales con sus pares de columnas, sus entrecalles y el trozo de entablamento sobre ellas. Se hacen nuevos por completo los podios laterales, incluidas las credencias, el registro central, que forma un camarín y en el que habría dos imágenes más de las que ahora se ven y el cuerpo del ático con hornacina central para albergar el Sacramento, dos ángeles portadores de reliquias y seis niños ${ }^{19}$. Todas estas figuras infantiles que hoy producen un efecto extraño, sostendrían un suntuoso dosel con corona que fue eliminado hace algunos años por una desafortunada reforma. La apariencia original la hemos podido deducir y reconstruir gracias a una antigua foto ${ }^{20}$. El recortado perfil de este ático se prolonga hacia abajo por los costados del retablo con dos alerones de suculentas rocallas flameantes apoyadas inferiormente en tableros de cajeados mixtilineos (Fig. 2). Todos los rasgos de la ornamentación y figuras nuevamente talladas coinciden con el estilo de Acosta, a quien no dudamos en atribuir el conjunto ${ }^{21}$.

Es posible que también se deba a la mano de Cayetano un pequeño retablillo situado en el coro bajo del monasterio de San Clemente realizado para servir de marco a una pintura del Niño Jesús ${ }^{22}$. El vigor de su diseño denota la mano de

19. Actualmente en lugar de la custodia se expone una moderna imagen de la Inmaculada Concepción. Es probable que las dos santas que estaban situadas últimamente en el cuerpo bajo fueran del retablo realizado hacia 1700 y fuesen respectivamente Santa Bárbara y Santa Catalina, aunque hoy han perdido sus atributos originales. Es muy posible también que con la remodelación de Acosta, ambas fuesen colocadas en las repisas laterales del ático, a cuyo tamaño se ajustan perfectamente. Los dos santos que, sin embargo, ocupaban últimamente estos lugares tampoco se corresponden estilísticamente con el taller de Acosta y posiblemente se harían para ocupar los intercolumnios del cuerpo bajo. Se trata de San Felipe Benicio y Santa Juliana Falconieri, los santos fundadores de la Orden. Agradecemos a la Hermandad las facilidades prestadas para el estudio del retablo y a su actual secretario, don Francisco Luis Amador, las informaciones por él suministradas sobre las imágenes.

20. Debemos el conocimiento de esta fotografía al licenciado en Historia del Arte, José Fernando Gabaldón de la Banda, a quien agradecemos aquí su amabilidad al cedernos esta información gráfica. Igualmente, queremos expresar nuestro agradecimiento al Prof. Alberto Oliver, quien ha realizado la meticulosa y paciente reconstrucción del estado original del retablo que ilustra este trabajo.

2i. Lamentablemente la Hermandad perdió su Archivo, por lo que no se ha podido consultar documentación relativa a esta obra salvo una noticia del dorado posterior a la supuesta reforma de Acosta, dorado que se decide en cabildo de la Hermandad de 9 de febrero de 1772.

22. Esta obra fue reproducida por primera vez en la obra de VALDIVIESO GONZÁLEZ, Enrique y MORALES MARTÍNEZ, Alfredo: Sevilla oculta: monasterios y conventos de clausura, Sevilla, 1980, pag. 34. 
este artista. También por estas fechas, concretamente en 1763, se realiza la portada para la Casa de la Moneda, ejecutada en piedra, en cuyos detalles ornamentales probablemente intervino Cayetano de Acosta o su hijo Juan ${ }^{23}$.

Volviendo al ámbito familiar, hay que señalar que desde 1763, María de Acosta deja de constar en el domicilio paterno ya que se casa con Cristóbal Antonio de Ribera (Ap. Doc. $\mathrm{n}^{\circ}$ 5). Tampoco figura en el registro desde 1765 Agustina de Acosta, probablemente por fallecimiento ${ }^{24}$.

Por esas fechas (1764-65) Acosta talla los leones que rematan las columnas ornamentales del Paseo de la Alameda ${ }^{25}$, lugar de esparcimiento a pocos metros de su casa que se reforma por estos años.

También por entonces realiza las esculturas alegóricas de los ríos Guadalquivir y Eridanu flanqueando el escudo real, conjunto petreo que remata el Palco del Príncipe de la plaza de Toros de la Real Maestranza de Caballería de Sevilla ${ }^{26}$.

Hacia 1765 pudo realizarse en su taller o en el de alguno de sus discípulos más cercanos la imagen de mármol de la Inmaculada Concepción que se coloca sobre la portada de las escuelas de beneficencia edificadas junto al seminario jesuita de San Luis de los Franceses (Lám. 3). El enmarcamiento de la portada se adorna con rocallas de traza muy vigorosa cercana al estilo de Acosta ${ }^{27}$.

Desde 1765 hasta 1769 no se registran acontecimientos familiares relevantes en la casa de Cayetano e Isabel. Por entonces Acosta acomete su obra más atrevida, el retablo-embocadura y arreglo de la capilla Sacramental en la iglesia colegial del Salvador ${ }^{28}$. La ficha del padrón, que hasta ese momento se ha

23. Cfr.: ESPIAU EIZAGUIRRE, Mercedes: La fachada de la Casa de la Moneda, "Archivo Hispalense" n 202, (Sevilla, 1986), pag. 195.

24. Desde 1763 hasta 1765 vive con la familia Doña Agustina González, viuda, de la que no conocemos más información. Sólo constatamos la coincidencia de apellido con Diego González que se casará pronto con Andrea de Acosta. No sabemos si era su tía e ignoramos qué motivo la llevó a vivir con la familia durante este período.

25. PLEGUEZUELO HERNÁNDEZ, Alfonso: Sobre Cayetano de Acosta... pag. 36.

26. Véase HALCÓN ALVAREZ-OSSORIO, Fátima: El palco del príncipe de la Real Maestranza de Caballería de Sevilla, "Revista de Arte Sevillano" $n^{\circ} 3$ (Sevilla, 1983), pags. 83-87.

27. El edificio se levanta entre marzo de 1764 y marzo de 1765 según indica una inscripción que fue transcrita por GONZÁLEZ DE LEÓN, Félix: Noticia artística ........ pag. 457 con el siguiente texto: "D. Nicolás de Robles, natural de la ciudad de Palencia. Vecino y del comercio de esta ciudad, fundó Estas escuelas de leer, y escribir; y después de su fallecimiento, que fue a primero de Enero de 1763, su muger Doña Dionysia de Encinas, natural de esta Ciudad, en cumplimiento de la Voluntad de su Marido dio principio a la fabrica de dichas escuelas a 5 de Marżo de 1764, cuya primera piedra se colocó a 22 de Abril del mismo año. Se concluyó la fábrica a 23 de Marzo de 1765, y se abrieron las escuelas para la enseñanza pública a seis de Mayo del mismo año de 1765. A mayor honra y gloria de Dios". Puede consultarse alguna documentación referente a esta fundación en el Archivo Municipal, Papeles del Conde del Águila. Tomos en cuarto, $6^{\circ}$, Doc. $n^{\circ} 7$.

28. La obra fue ya atribuida por CEÁN BERMỨDEZ, Agustín: Diccionario Histórico de los más ilustres Profesores..., (Madrid, 1800), pags. 2,3 y 4. 
mantenido en un total laconismo al respecto de la profesión de los censados, describe en 1769 a Cayetano como "maestro escultor" de sesenta años. Sus hijos Francisco (debe referirse a Francisco Antonio), de veintisiete y Andrés, de quince, son citados respectivamente como "escultores con su padre".

En 1769 se registra por última vez Francisco Antonio, quien por entonces se casa con Vicenta de Cáceres (Ap. Doc. $n^{\circ} 6$ ).

A estas alturas, en 1770, sólo quedaban viviendo con Cayetano e Isabel los dos más pequeños, Andrea, de veintiún años y Andrés, de diecinueve. Este último se casa en 1771 con Joaquina de Segura ${ }^{29}$ abandonando el domicilio paterno. Sin embargo en 1774, aparece su esposa viviendo con sus suegros y su cuñada Andrea. Es probable que Andrés se ausentara temporalmente del domicilio para realizar algún trabajo y dejara a su joven esposa en compañía de sus ya ancianos padres y de su hermana, de la misma edad que ella y aún soltera. No obstante, es extraño el hecho pues durante estos años (1770-1779) el equipo familiar en el que Andrés debía ser ya un elemento importante, concentrará sus fuerzas en otro de los fantásticos "disparates" que levantaría ampollas en las conciencias bienpensantes de los neoclásicos: el retablo mayor de la Iglesia Colegial del Salvador, que fabricaría en compañía de sus hijos el ya por entonces más que sexagenario portugués. Cayetano no tuvo la satisfacción de ver terminada su última gran obra. De este retablo comentaría Llaguno que: "solamente el del sagrario de la Catedral de Sevilla y el famoso transparente de Toledo pueden competir con él en desatino" ${ }^{30}$. No sale precisamente malparada la obra de Acosta con este pretendido insulto.

Difíciles de fechar pero atribuibles a la obra de este mismo escultor son, a mi parecer, los dos ángeles lampareros sobre peanas de rocalla sostenidas por un Niño y tres querubes que flanquean el retablo mayor de la iglesia del Colegio de San Alberto (Lám. 4). El parecido con los ángeles lampareros de la iglesia del Salvador, con los que pueblan el retablo Sacramental de esta misma iglesia o los del Convento de Santa Rosalía, podría avalar esta nueva atribución.

Mientras se ejecuta el conjunto de la capilla mayor de la citada iglesia colegial, Joaquina, mujer de Andrés, hará compañía a sus suegros durante dos años más. En 1775 se casa Andrea con Diego González (Ap. Doc. $\mathrm{n}^{\circ}$ 7), viviendo durante dos años el joven matrimonio con los padres de la novia y la cuñada de ambos ${ }^{31}$.

29. Archivo General del Arzobispado. Sección: Expedientes Matrimoniales, leg. A-142 (1771), Partida ${ }^{\circ} 39$.

30. LLAGUNO Y AMIROLA, Eugenio: Noticia de los arquitectos... Tomo IV, Madrid, 1829, pag. 71. Para una información más completa de esta obra puede consultarse el trabajo de GONZÁLEZ GÓMEZ: Juan Miguel: El retablo mayor del Salvador de Sevilla, obra póstuma de Cayetano de Acosta (1771-1779) "Archivo Hispalense" (Sevilla, 1988), Tomo LXXI n 217, pags. 253-272.

31. En relación con la boda de Andrea no queremos dejar de consignar una noticia curiosa por la coincidencia de nombres y apellidos. Una tal Andrea Cayetana de Acosta recibió una dote de 6.000 reales del Cabildo Municipal para casarse en 1772 con Vicente Ortiz. El 2 de mayo siguiente se había celebrado ya la boda (Archivo Municipal, Sección $2^{\mathrm{a}}$ (Contaduría). Carp. 62 (1772), Doc. 44). Realmente no debe tratarse de la hija de Cayetano pues ni era Cayetana su segundo nombre de pila, ni en su acta matrimonial de 1775 aparece como viuda de Vicente Ortiz. 
Resulta admirable la fortaleza física de Acosta quien con cerca de setenta años, realiza en 1776 la gran Inmaculada Concepción para la Hermandad Sacramental del Sagrario, hoy en el Palacio Arzobispal ${ }^{32}$. Podría pensarse que en esta obra de enorme envergadura, sus hijos pudieran haberle ayudado, pero la excepcional calidad que revela hasta en sus más mínimos detalles no se corresponde con otras obras documentadas de sus hijos lo que nos obliga a pensar en la intervención directa del anciano maestro.

En 1777, Cayetano, a sus 68 años e Isabel con 66, por primera vez en su ajetreada vida de padres de familia numerosa, se quedan solos. No obstante, su hijo Francisco Antonio (el menor) vivía en una casa pocos metros más arriba de la misma calle y su otro hijo, Francisco de Asís (el mayor), en otra calle muy cercana.

Cayetano de Acosta fallece en 1778 y no en 1780 como comenta Ceán ${ }^{33}$ y es enterrado el 24 de abril ${ }^{34}$. Había otorgado en 1754 poder notarial para testar a favor de su mujer ante el -escribano público de Sevilla José Prieto Muñoz ${ }^{35}$. Después de su fallecimiento, la viuda procede a hacer el aprecio de los bienes familiares, documento que lamentablemente no hemos llegado a conocer, por haber sido, al igual que el anterior, sustraído del libro de la escribanía ${ }^{36}$. Al mismo tiempo que se realiza el inventario, Isabel de Amil hace testamento ante dicho escribano con fecha de 15 de junio de 1778 , documento éste que también falta de su lugar ${ }^{37}$.

A la muerte del artista comparecen como herederos siete hijos y su viuda (Fig. 3). Por petición de ésta última se procedió al cumplimiento del testamento y la partición del caudal heredado. Con fecha de 2 de marzo de 1779 se procede a la venta del corral llamado de Marco Sancho, el mayor de los dos que Acosta había

32. VALDIVIESO GONZÁLEZ, Enrique: Una Inmaculada inédita de Cayetano de Acosta, "Archivo Hispalense" (Sevilla, 1981), Tomo LXIV n 196, pags. 143-145.

33. PERALES PIQUERES, Rosa $\mathrm{M}^{\mathrm{a}}$ : Nuevos datos biográficos sobre el escultor Cayetano de Acosta, "Revista de Arte Sevillano" $n^{\circ} 1$ (Sevilla, 1982), pags. 62-63.

34. Joaquina de Segura figurará también viviendo con su suegra Isabel de Amil en el primer año de viudedad de ésta, (1779) y, al año siguiente (1780), también su marido Andrés de Acosta aparece compartiendo la casa con su madre.

35. Sobre este poder notarial se conocen dos referencias documentales: una, correcta, en la Partida de Defunción y otra, errónea, en la escritura de compraventa de casas de 1779 (Apéndice Documental $n^{\circ} 8$ ). En esta última se citan sin error el día y el mes pero inexacto el año, ya que se fija el de 1750 en lugar de 1754. La referencia correcta del Archivo de Protocolos Notariales de Sevilla (Oficio VII. 1754. Vol. II. 20 de febrero), se confirmó a través de los índices de dicha escribanía pero, realizada la búsqueda, pude comprobar que el lugar del documento estaba vacío y con huellas evidentes de haber sido arrancado.

36. Archivo de Protocolos Notariales. Oficio VII. 1778. Fol. 253. Esta referencia ha sido tomada del índice de dicho oficio.

37. Archivo de Protocolos Notariales de Sevilla. Oficio VII. 1778. Vol. I. Fol. 230. La referencia exacta ha sido tomada de los índices de este Oficio. Debemos aclarar aquí que, además de faltar este documento, también faltaba de su lugar otro cuya referencia en los índices indicaba ser un "Reconocimiento de tributo/ Cayetano de Acosta a la Redención de cautivos" . Oficio XX. 1770. Fol. 341. 
comprado en 1758 (Ap. Doc. $n^{\circ} 8$ ). Parece por el documento que este inmueble había correspondido a Isabel de Amil, Antonia de Acosta y Andrea de Acosta. Todas ellas, de común acuerdo, se lo venden a un tal Joaquín Valvidares, vecino de la misma collación.

Cuando se efectúa esta operación, Andrea vive, imagino que circunstancialmente, en casa de su hermana Antonia, frente al Baratillo en la collación del Sagrario. Andrea de Acosta se hallaba en trámites de separación de Diego González, por lo que para acudir al acto notarial tuvo que lograr previamente un permiso especial del juez, al no poder obtenerlo de su marido. No tiene nada de extraño que a causa de este problema conyugal estuviese atravesando una situación económicamente difícil y que ello la llevara a solicitar su parte de la herencia valorada en 7.632 reales.

En este documento de venta no se nombran ni la casa de la calle de la Tinaja, donde aún vivía la viuda, ni el corral de la calle Cañaverería. No es de extrañar que ambos inmuebles hubieran correspondido en la partición de bienes a los demás hermanos y que no conviniera venderlo si en la primera vivía la viuda y en el segundo tenían instalado, como pensamos, el taller y la vivienda de la familia de Francisco de Asís, como así parece por el padrón.

Después de efectuarse las particiones, en 1781, Isabel de Amil, a pesar de su edad, aparece viviendo sola. No obstante, factores que desconocemos -no sabemos si de índole afectiva o económica- hicieron variar la situación del matrimonio de Andrea de forma que esta, su marido y su hijo, aparecen viviendo con la abuela desde 1782 a 1786 .

Isabel de Amil, en los últimos años de su vida, vivió en su casa en compañía de diversas personas cuyos nombres no parecen relacionarse con su familia. No encontramos explicación para este hecho, a no ser que la viuda se ayudase alquilando habitaciones de la casa a distintas personas. Pero esto se contradice con la situación financiera más que holgada que se deduce de los 66.426 reales que Acosta había dejado como caudal a su muerte, de los cuales la mitad correspondieron a su viuda. En 1793 la casa aparece vacía. Isabel, ya muy anciana, se había trasladado a vivir con su hija mayor, Antonia. Dos años después, fallece a los 84 años ${ }^{38}$.

Hasta aquí hemos expuesto lo que se refiere al núcleo familiar que surge entorno al matrimonio de Cayetano de Acosta e Isabel de Amil. En adelante esbozaremos de forma muy somera varios datos que hemos podido recoger de las familias que forman algunos de los hijos varones del escultor, que siguen profesionalmente los pasos de su padre ${ }^{39}$.

38. Archivo Parroquial del Sagrario. Libro de Entierros (1782-1806). Fol. 127 vto.

39. Considerando que la personalidad artística de estos aún permanece casi desconocida y pendiente de valoración, a partir de aquí no me detendré en pormenores ni se transcribirá el texto integro de la actas de bautismos y matrimonios aunque sí proporcionaré sus referencias documentales y algunos datos más por si en un futuro pudieran ofrecer interés. 
Todo apunta a considerar a Juan de Acosta como el primogénito de la familia y aunque no sabemos en qué año nace, debió ser hacia 1730-1732. Es muy probable que colaborase con su padre en las obras de piedra que aquél pudo contratar en su primera y enigmática etapa sevillana y debió ser ya un oficial plenamente formado cuando viven en Cádiz. También debió participar, junto a su hermano Francisco de Asís, en la obra de la Real Fábrica de Tabacos, como deducimos de un comentario expresado por Don José Quevedo en carta fechada en agosto de 1756 dirigida al Superintendente. En ella escribe: "... en acabar los remates de la Portada y la Estatua (la Fama)... será preciso que V.m. con toda su seriedad estreche al Estatuario (Cayetano de Acosta) y a sus hijos para que concluya esto..." ${ }^{40}$. Juan, tras finalizar su participación en la Real Fábrica, busco otros encargos ya que lo encontramos en 1758 cobrando como oficial de cantería en los Reales Alcázares ${ }^{41}$.

Su obra, conocida solo documentalmente, parece que siempre la ejecutó en piedra. De hecho, en 1762 figura como oficial de cantería en la lista que elabora el maestro Alfonso Prieto con todos los que entonces se encuentran activos en Sevilla en tal oficio ${ }^{42}$. En 1775, contando 45 años, aparece matriculado en la sección de Arquitectura de la Escuela de las Tres Nobles Artes ${ }^{43}$. En esta tardía formación -tal vez forzada por una consciente voluntad de actualizar y perfeccionar su adiestramiento empírico- es probable que asimilara los contenidos neoclásicos de estas enseñanzas académicas, pero es difícil conocer por ahora cuál fue su concreta forma de hacer mientras no se documenten e identifiquen sus obras.

En cuanto al segundo varón, Francisco de Asís y Acosta, sabemos que se casa con Felipa de Cáceres hacia 1760 como ya se ha señalado ${ }^{44}$. Durante los

\footnotetext{
40. CARRERA SANABRIA, Manuel: Más sobre Cayetano de Acosta... pag. 394.

41. "Razón de la Cantería que se va trabajando en la obra ... en la Galería que está enfrente de de $\mathrm{M}^{\mathrm{a}}$ de Padilla ... en la semana $2^{\mathrm{a}}$ que principia en 27 de febrero y acabó en 4 de marzo del año presente" (1758). Entre los oficiales de cantería se paga a Juan de Acosta por su labor. Archivo de los Reales Alcázares, Leg. 227, Dto. $\mathrm{n}^{\circ}$ 6. También se le abona por los mismos conceptos en el documento $\mathrm{n}^{\circ} 7$. Se conserva un escudo real en dichos Alcázares, en la galería abierta al sur en el Jardín de la Alcobilla, realizado en una talla rococó bastante fina que tal vez podría ser atribuido al círculo de Cayetano de Acosta. Una guarnición de rocalla que rodea la puerta de acceso a los salones de Carlos V desde el pórtico del Patio del Crucero proyectado por Sebastín van der Borcht, resulta de factura bastante tosca y no parece vincularse a Cayetano de Acosta aunque tal vez pudiera haber intervenido en ella su hijo Juan.
}

42. PLEGUEZUELO HERNÁNDEZ, Alfonso: Sobre Cayetano Acosta.... pag. 41.

43. Debo el conocimiento de este dato a la licenciada Rosa María Perales Piqueres.

44. No sabemos si Felipa de Cáceres tenía alguna relación con Sebastián de Cáceres, un oficial tallista y ensamblador que figura en la lista citada de 1762 junto a los jóvenes Acosta (Véase PLEGUEZUELO HERNÁNDEZ, Alfonso: Sobre Cayetano de Acosta... pag. 41.) o si más bien es hija de Fernando de Cáceres, el platero que había colaborado en 1770-72 con Cayetano en las esculturas de San Leandro y San Isidoro para el trono de plata de la Catedral (Véase PALOMERO PARAMO, Jesús M.: La Platería en la Catedral de Sevilla en "La Catedral de Sevilla", Sevilla, 1984, pags. 585-588). Tal vez no sea coincidencia el hecho de que por la década de los cincuenta una Felipa de Cáceres viviera en la misma calle Canaverería con varios individuos del mismo apellido entre ellos un Fernando de Cáceres. 
primero años de vida conyugal habitan en una calle de la misma collación de San Martín, pues en su pila son bautizados sus primeros hijos. Este matrimonio fue más prolífico aún que el de Cayetano e Isabel, pues tuvieron doce hijos. Antes de mudarse a la calle Cañaverería vinieron al mundo María Dolores en 1763, Francisco de Asís en 1764, Juan de Dios en 1765, María de los Ángeles en 1766, Cirila Serapia en 1767, Thoribio en 1770 y Melchora en $1773^{45}$.

Como ya se sugirió más arriba, es probable que el propio corral de esta calle que pertenecía a Cayetano, fuese también a los pocos años, la residencia de su hijo escultor Francisco de Asís, cuando se casa. Al menos, en esa misma calle Cañaverería, aparece registrado en los padrones desde 1773.

Viviendo allí, nacerán Cayo en 1776, Genoveva en 1778, Marcela en 1779, Plácido en 1780 y Estefanía en 1783. En este último año se casa ya Juan de Dios con María de Aguilar ${ }^{46}$, vecina también de la misma calle. Cuatro años más tarde (1787), Cirila se casará con Manuel Felipe Romero ${ }^{47}$; en Septiembre del año siguiente lo hará el primogénito, Francisco de Asís con Andrea González, vecina de la Alameda, lugar donde vivirá el joven matrimonio ${ }^{48}$ y a fines del mismo mes y año María de los Ángeles Acosta se casa con el conocido escúltor italiano Juan Bautista Patrone, según la partida matrimonial, natural de Génova (Ap. Doc. $\mathrm{n}^{\circ}$ 9).

Es muy probable que Francisco de Asís y Acosta, el padre, falleciera a finales de 1789, ya que deja de figurar en el padrón desde esa fecha y Felipa de Cáceres aparece poco después como viuda. Cuando esto ocurre aún quedaban en la casa varios hijos solteros y será Juan Bautista Patrone quien se constituya en el nuevo cabeza de familia y saque adelante el resto de la prole de su suegro. En 1799 aún vivían en la casa el escultor genovés, su mujer, su hijo Santiago, la abuela, Felipa de Cáceres y sus hijas Genoveva, Marcela y Estefanía, aún solteras.

Una obra recientemente documentada como de un Francisco de Acosta -el sagrario-manifestador ejecutado en 1783 para un retablo que Juan de Valencia había realizado a principios del setecientos para la iglesia parroquial de Bornos (Cádiz) -es el único testimonio de que su autor- al que identificamos con Francisco de Asís -mantiene decididamente una línea estilística rococó hasta la década de

45. Archivo Parroquial de San Martín (hoy en San Andrés). Libro de Bautismos n 10 (1727-1774). Fols. 279, 297-297 vto., 311-311 vto., 334 vto. y 364. Las fechas de Mª Dolores y Juan de Dios fueron deducidas del padrón parroquial.

46. Archivo Parroquial de San Martín (hoy en San Andrés). Libro de Matrimonios (1749-1785). Fol. 367. No sabemos si es familia de Christobal de Aguilar que figura en la ya citada lista de 1762.

47. Archivo Parroquial de San Martín (hoy en San Andrés). Libro de Matrimonios (1785-1807). Fol. 27. No sabemos si el marido de Cirila de Acosta está relacionado familiarmente con José y Laureano Romero tallistas y ensambladores de la nombrada lista de 1762 .

48. Archivo Parroquial de San Martín (hoy en San Andrés). Libro de Matrimonios (1785-1807). Fols. 21-21 vto. 
los ochenta ${ }^{49}$. Las estructuras están literalmente revestidas de rocallas y el orden arquitectónico, oculto entre ellas, pero carece de la expresividad, el rigor y la valentía de las obras de Cayetano.

Ya hemos comentado antes que Francisco Antonio se casa en 1769. Igual que su hermano mayor, lo hace con una mujer también de apellido Cáceres, pero de nombre Vicenta ${ }^{50}$. El matrimonio se queda a vivir, como ya se ha referido más arriba, junto a la casa de Cayetano e Isabel, en la calle de la Tinaja. Francisco Antonio siguió también la misma profesión de su padre, como se comprueba al aparecer en la lista de oficiales tallistas y ensambladores de 1762 y en la citada ficha del padrón parroquial de 1769.

Este matrimonio no será tan prolífico como el de su hermano Francisco de Asís y sólo tendrán tres hijos: Andrés, el mayor de ellos, nacido en 1770, Manuel, nacido al año siguiente ${ }^{51}$ y María de la Paz, que viene al mundo hacia 1775 . Al primogénito le perdemos la pista cuando tiene quince años. Manuel debió fallecer muy pequeño, ya que nunca llega a figurar en el padrón y María sabemos que tenía cumplidos doce años cuando en 1788 la familia completa desaparece del domicilio para mudarse a un lugar que por ahora desconocemos.

Consideramos casi seguro que sería éste hijo de Cayetano el Francisco de Acosta que figura matriculado en la Escuela de las Tres Nobles Artes en la sección de Pintura en 1775 y en la de Arquitectura en ese mismo año y en 1783. Es comprensible que fuese el más joven y con menos carga familiar de los hermanos el que decidiera, poco antes de fallecer su padre, iniciarse en el estilo que ya era dominante en los círculos artísticos más refinados de la ciudad. Francisco Antonio pudiera haber experimentado así un cambio de estilo al haber recibido una primera formación barroca tardía junto a su padre e iniciarse más tarde en el lenguaje neoclásico de la Academia.

Se conservan unas pocas obras de un Francisco de Acosta, alguna de ellas en la propia parroquia de San Martín, en las que creemos identificar la labor de Francisco Antonio. Son retablos y cajas de órganos realizados en madera, decorados imitando jaspes, de un marcado carácter neoclásico que este artista imprimiría a sus obras, al menos desde principios de los ochenta ${ }^{52}$.

49. RÍOS MARTÍNEZ, Esperanza de los: Una obra inédita de Juan de Valencia: el retablo mayor de la iglesia Parroquial de Bornos, "Laboratorio de Arte" $n^{\circ} 3$ (Sevilla, 1990), pags. 63-86.

50. Por los datos de sus padres, se sabe que no es hermana de su cuñada aunque tal vez ambas estaban emparentadas entre sí y/o con el tallista o el platero del mismo apellido ya citados antes. Vicenta era al menos vecina de San Martín ya que vivía en la misma calle que la familia de Cayetano.

51. Archivo Parroquial de San Martín (en San Andrés). Libro de Bautismos no 10, Fols. 338 vto. y 352 respectivamente.

52. Sancho Corbacho, entre otras noticias de la obra de este artista, da a conocer incluso un proyecto conservado para un órgano y su tribuna para la iglesia de Campillos (Málaga). Véase SANCHO CORBACHO, Antonio: Arquitectura barroca sevillana del siglo XVIII, (Madrid, 1954), pag. 29 
Después de esta tediosa lista de fechas y nombres, convendría hacer balance y dar respuesta clara a la incógnita inicial acerca del hijo y el nieto de Acosta que pudieron ser sus más cercanos seguidores. Contando con que Juan de Acosta se decantó por el trabajo de la piedra, es lógico que el sucesor de Cayetano en la madera fuese el segundo de los varones: Francisco de Asís, puesto que por generación, el tercero de ellos, Francisco Antonio, por formarse unos años más tarde, sería el más proclive a opciones estilísticas más avanzadas. En suma, aunque su obra se distinga, sobretodo por su inferior calidad, sería Francisco de Asís y Acosta quien seguiría la forma de hacer de Cayetano.

Respecto del nieto al que Ceán convierte también en seguidor del maestro portugués, podemos proceder por exclusión. Los hijos del joven Andrés de Acosta quedan descartados por razones generacionales. Tampoco pudo ser ninguno de los hijos de Francisco Antonio. Con independencia de que éste les habría aleccionado ya dentro del nuevo credo que él mismo había aprendido en la Academia años antes, el primogénito desaparece a los quince años y el segundo muere con seguridad muy pequeño.

Entre los hijos de Francisco de Asís, a partir del tercero, Thoribio, no tuvieron siquiera oportunidad de aprender con su padre que fallece relativamente joven. Es más, lo más probable es que fuese el nuevo cabeza de familia, su tío Juan Bautista Patrone, convencido neoclásico, a quien éstos pudieran haber tenido por maestro en el taller familiar. Por todo ello, los únicos que quedan como candidatos serían los dos hijos mayores de Francisco de Asís: el primero, llamado como su padre, y el segundo, Juan de Dios. Es probable, pues, que fuera uno de estos dos, tal vez el primero de ellos, el nieto de Acosta al que Ceán acusa de continuador, por no llamarle "continuista" del arte "monstruoso", "pueril" y "extravagante" de su abuelo.

El joven Francisco de Asís, teniendo un maestro como su padre, que veinte años después de nacer él todavía se mantiene incólume en su línea rococó, no es de extrañar que continuara convencido de que el ya exhausto estilo "chinesco", como se le había llamado en sus inicios, aún podía dar frutos en 1800 , cuando Ceán entra a saco en el debate acusando a los esbirros saguntinos de Cayetano de Acosta de continuadores de un estilo que no sólo le resultaba "abominable" sino, lo que era peor para un "moderno" como él, también obsoleto ${ }^{53}$.

Pero por muy excelente que consideremos la obra del iniciador de esta auténtica saga, que lo es y en grado sumo, a tenor de la discreta calidad general de la producción rococó sevillana conservada de fines del siglo XVIII, puede colegirse que estos acostianos no pasaron de ser unos artesanos aventajados, pero incapaces de mantener el nivel de calidad de la obra de su progenitor e insensibles para captar los evidentes atractivos que la nueva estética neoclásica ofrecía. Pero me temo que no se trataba de un empecinamiento personal, sino más bien de un clima generalizado en los círculos artísticos de la ciudad.

53. Para conocer más en profundidad y extensión el debate Barroco-Neoclásico en Sevilla vease el completo trabajo de SERRERA, Juan Miguel: Los ideales neoclásicos y la destrucción del barroco, "Archivo Hispalense" $n^{\circ} 223$ (Sevilla, 1990), pags. 135-159. 
Y lo peor de todo es que, en una Sevilla como la de 1800, artísticamente anclada en un gusto barroco ya retardatario, y culturalmente deprimida hasta límites insospechados, los paladines locales del nuevo estilo no fueron sino modestísimos émulos de sus prototipos oficiales pues si el barroco tardío sevillano de fines del XVIII era ya un arte sin vigor y degradado, su neoclásico contemporáneo y posterior no fue menos mediocre. De hecho, las mejores obras del nuevo estilo, tanto arquitecturas como esculturas, se encargaron a "profesores" foráneos, sobre todo de Cádiz y de Madrid. Estaba claro, que la ciudad y sus artistas habían perdido un tren que tardarían muchas décadas en retomar trabajosamente.

En un asunto no estuvieron faltos de lucidez los furibundos neoclásicos. Y fue cuando, refiriéndose a los retablos y esculturas del siglo XVIII sevillano, declararon que nuestro difamado portugués era, afortunadamente para ellos, el último de una triada que había nacido con Balbás, siguió con Duque Cornejo y se extinguió con Acosta. Pasado el tiempo y serenados los ánimos de aquella polémica que vió en estos tres artistas a los responsables de la "corrupción del gusto", no veo inconveniente en reconocer el valor de la obra de los que, tomando prestada la expresión de Gómez Moreno, podríamos calificar de "las águilas" de nuestro barroco sevillano dieciochesco. 


\title{
APÉNDICE DOCUMENTAL
}

\begin{abstract}
Documento número 1
Partida bautismal de Andrés de Santa Ana. Archivo Parroquial del Sagrario, Libro de Bautismos $n^{\circ} 63$ (1748-1752), fol. 193 vto.

"En tres de Agosto de mil setecientos cincuenta y un años, yo el Licenciado Don Pedro Muñoz de Zarate, cura del Sagrario de esta Santa Patriarcal Iglesia de Sevilla; bauticé a Andrés de Santa de los Ángeles que nació día veinte y seis del próximo pasado, hijo de Don Cayetano de Acosta y Isabel de Amil, su mujer, fueron padrinos Andrés Moreno y María de Amir, a quienes advertí el parentesco espiritual y sus obligaciones. Fecho ut supra."
\end{abstract}

\section{Documento número 2}

Contrato de compra-venta de casas entre los herederos de Marco Sancho y Cayetano de Acosta. Archivo de Protocolos Notariales de Sevilla. Oficio 17, 1758. Vol. II. fols $875-898$ vto.

"Sepan cuantos esta carta de venta vieren como nos Doña Josefa Sancho, mujer legítima de Felipe Algumedo y Doña María Sancho, hermanas de estado doncellas mayor de veinticinco años vecinos de esta ciudad de Sevilla en la collación de San Martín... y Marco Sancho, vecino de la villa de Coria al presente en esta ciudad por mí mismo y en nombre de Doña Micaela Sancho, mi hermana, mujer legítima de Don Pedro Serrano, vecinos de la ciudad de Cádiz y en virtud del poder

(aquí va insertado el poder)

herederos únicos que somos ... de Marcos Sancho y Doña Ángela Díaz Bachiller, nuestros padres difuntos

(testamento)

y así mismo, la referida Doña Ángela Díaz Bachiller, nuestra madre... nos instituyó por tales herederos con otro que ya es difunto en el testamento que otorgó... ante José Fernández de Cosgaya... por lo cual hemos quedado los cuatro otorgantes por tales herederos únicos... otorgamos que vendemos ... a Don Cayetano de Acosta, vecino de esta ciudad para el susodicho, sus hijos, herederos y demás personas... dos casas y dos corrales de vecindad que están en esta ciudad; las dos casas en la calle del Pepino en la collación de San Martín ...; y los dos corrales el uno que es el chico al sitio de la Cañaverería en la misma collación ... y el otro corral grande que esta en la calle de la Rosilla que tiene dos puertas una a esta y otra que sale a la Cruz del Rodeo y linda por la dicha calle con casas de Geraldo Martiel y con el Convento de San Benito de Calatrava que está al final de la Alameda yendo para la Puerta de la Barqueta, y entrando en el dicho corral por la Cruz del Rodeo, linda con casas del convento de monjas de Santa María de Gracia de esta ciudad y casas de Juan Ruiz, cuyos dos corrales se componen de sus aposentos bajos y su pozo y las casas con vivienda alta y baja y nos pertenece todo en esta manera: las referidas dos casas siendo solar y perteneciendo el uno de ellos a la Fábrica de la Iglesia de San Martín...= y otro solar y cobertizo que en lo antiguo se debía estar en la calle del 
Tarajo (sic) o Tinaja que tenía su entrada componiéndose de cuatro varas y media de fachada y por la calle del Pepino diez y ocho y media que hacían superficiales ciento y siete varas y lindaba por la calle del Pepino con casas de Don Gregorio de Contreras... y fue apreciado con sus materiales que tenía en seiscientos setenta y ocho reales de vellón ... y vendemos al citado Don Cayetano de Acosta las enunciadas dos casas y dos corrales, sus entradas y salidas... con el cargo de los expresados tres tributos que ha de pagar y reconocer a sus señoríos desde el dis primero del mes de septiembre en que estamos de este año... en precio y cuantía de veinte y un mill y seiscientos reales de vellón que por el valor de dichas cuatro fincas nos ha ...pagado y del susodicho confesamos haberlos recibido ahora... y yo el dicho Cayetano de Acosta... recibo en mi compradas de los enunciados Doña Josefa Sancho y Felipe de Algumedo, su marido, Doña María Sancho, Marcos Sancho por sí y en nombre de Doña Micaela Sancho, vecina de la ciudad de Cádiz, las enunciadas casas linde la una con la otra en la calle del Pepino, collación de San Martín y dos corrales con sus aposentos bajos, el uno en la Cañaverería en dicha collación y el otro en la Cruz del Rodeo, collación de Omnium Sanctorum....

Fecha la carta en la ciudad de Sevilla a 16 de septiembre de 1758-."

Firmado y rubricado: José Sancho, Marcos Sancho, Cayetano da Costa, Felipe Algumedo.

Documento número 3

Partida de matrimonio de Juan de Acosta y María Carballo. Archivo Parroquial del Sagrario. Libro de Matrimonios $n^{\circ} 27$ (1745-1754). fol. 172 vto.

"En lunes ocho días del mes de enero de mil setecientos cincuenta y tres años, yo el Doctor Don Manuel de Ocanto (sic) y Rivera, Teniente de Cura del Sagrario de esta Santa Iglesia Patriarcal de Sevilla con mandamiento del Señor Juez de ella y licencia de Don Francisco García Grano de Oro, cura más antiguo de dicho Sagrario, habiendo precedido en él dos amonestaciones con dispensa de la tercera, y así mismo dispensándose enteramente las tres amonestaciones de la ciudad de Cádiz y la de Carmona y no resultado impedimento de las que aquí se leyeron, desposé y casé por palabras de presente que hicieron legítimo matrimonio a Juan de Acosta, natural de esta ciudad hijo de Cayetano Alberto de Acosta y de Isabel de Amil con María Carballo, natural de Carmona, hija de Eusebio Carballo y de Bernabela Flosralla (sic), siendo testigos Don Juan Garrido y Don Luis de Escobar, vecinos de esta collación. Fecho ut supra."

\section{Documento número 4}

Partida de matrimonio de Antonio Moreno y Antonia de Acosta. Archivo Parroquial del Sagrario. Libro de Matrimonios n 28 (1754-1763). fol. 36.

"En Sábado tres días del mes de Mayo de mil setecientos cincuenta y cinco años Don José Bautista de Mora, presbítero de este Sagrario con licencia de mi el infraescripto cura de dicho Sagrario de esta Santa Iglesia de Sevilla y mandamiento... desposé...a Antonio Pascual Moreno, natural de esta ciudad, hijo de Juan Moreno y de 
Ana Martínez, juntamente con Antonia Agustina de Acosta, natural de la Villa de la Puebla de Cazalla (sic), hija de Cayetano Barbudo (sic) y de Isabel de Amil; fueron testigos Juan de Salazar, vecino de Triana y Andrés Moreno de esta collación. Fecho ut supra" Al margen se lee: "velados en 28 de Noviembre de 1759".

\section{Documento número 5}

Partida de Matrimonio de Cristóbal de Rivera y Maria de Acosta. Archivo Parroquial de San Martín (en San Andrés). Libro de Matrimonios (1749-1785), fol. 181 vto.

"En martes veinte y cuatro días del mes de mayo de mil setecientos y sesenta y tres, yo el Beneficiado Don José Hiṕlito Quiral, cura de esta Iglesia Parroquial del Señor San Martín de esta ciudad de Sevilla ... desposé y case por palabras de presente que hicieron legítimo matrimonio a Don Cristóbal Antonio de Rivera, natural de esta ciudad, hijo de Nicolás de Rivera y de Doña María Rodríguez; juntamente con Doña María de Acosta, natural de la ciudad de Cádiz, hija de Cayetano de Acosta y de Isabel de Amil, siendo testigos del dicho desposorio Don Nicolás de Rivera, Doña Vicenta de Rivera, vecinos de esta dicha collación y Jerónimo Ortiz, vecino de la collación de Omnium Sanctorum y otras personas. Celebraron este dicho desposorio en las casas de la morada de Don Eusebio García de Barrios, vecino de la collación del Sagrario de la Santa Iglesia al sitio de las Gradas y por que conste lo firme. Fecho ut supra".

\section{Documento número 6}

Partida de Matrimonio de Francisco de Acosta y Vicenta de Cáceres. Archivo Parroquial de San Martín (en San Andrés). Libro de Matrimonios (1749-1785), fols. 231 vto.-232.

"En lunes quince días del mes de mayo de mil setecientos sesenta y nueve, yo el Beneficiado Don José Hipólito Quiral, cura de esta Iglesia Parroquial de San Martín de esta ciudad de Sevilla ... despose y case por palabras de presente que hicieron legítimo matrimonio a Francisco de Acosta, natural de la ciudad y obispado de Cádiz, hijo de Cayetano de Acosta y de Isabel María de Amil, juntamente con Vicenta de Cáceres, natural de esta ciudad, hija de Juan de Cáceres y de Josefa Martínez: siendo testigos del dicho desposorio Francisco de Acosta, Josefa Martínez y Josefa Navarro, todos vecinos de esta collación y otras personas. Celebrose este dicho desposorio en las casa de morada de dicha contrayente al sitio de la calle que llaman de Marco Sancho y porque conste lo firma fecho ut supra".

Se hicieron las velaciones en domingo 24 de junio de 1770, (fol. 237). 
Documento número 7

Partida de Matrimonio de Diego González y Andrea de Acosta. Archivo Parroquial de San Martín (en San Andrés). Libro de Matrimonios (1749-1785), fols. 285 vto.-286.

"En martes veinte y seis días del mes de julio de mil setecientos setenta y cuatro yo el Beneficiado Don José Hipólito Quiral, cura de esta Iglesia Parroquial, desposé y case por palabras de presente que hicieron verdadero y legítimo matrimonio a Diego González, natural de esta ciudad, hijo de Elías González y de Inés de Acevedo: juntamente con Andrea de Acosta, natural de la ciudad de Cádiz, hija de Cayetano de Acosta y de Isabel de Amil, siendo testigos del dicho desposorio Manuel González, Florencio González, vecinos de la collación del Sagrario de la Santa Iglesia y Benito Pereira, vecino de la collación de Santa María Magdalena y otras personas: celebrose este dicho desposorio en las casas de la morada del dicho cura al sitio de la Calle Ancha de San Martín y porque conste lo firme fecho ut supra".

Se hicieron las velaciones en 20 de octubre de 1776 (fol. 305 vto.)

\section{Documento número 8}

Contrato de compra-venta entre herederos de Cayetano de Acosta y Joaquín Valvidares. Archivo de Protocolos Notariales de Sevilla. Oficio 17. 1779, fol.s 447-455 vto.

"sepan cuantos esta carta vieren cómo nos Doña Isabel de Amil, viuda de Don Cayetano de Acosta, vecina de esta ciudad de Sevilla, en la collación de San Martín = Doña Antonia de Acosta, mujer legítima que soy de Don Antonio Moreno, vecina extramuros de esta ciudad fuera de la Puerta del Arenal en la acera de mano derecha frente al Baratillo, collación del Sagrario, ..= y Doña Andrea de Acosta, mujer legítima de Diego González, vecina también extramuros de esta ciudad frente al Baratillo, ...mediante la separación de mi marido y precedida información de lo referido me fue concedida (licencia) para otorgar los instrumentos que fuera necesarios por el señor Alcalde Don Ignacio Luis de Aguirre ante Marcelino de Avaría, Escribano de su Provincia, según consta de su testimonio que dio y firmó y después será inserto $=$ y todas tres son presentes, la primera viuda y las otras dos como dos de los hijos y herederos únicos y universales que dejó nombrados Don Cayetano de Acosta, en el poder para testar que tenía dado a mi ... Doña Isabel ... y paso ante José Prieto Muñoz, Escribano Público que fue de Sevilla en veinte del mes de febrero del año de mil setecientos y cincuenta, yo el testamento que en virtud del citado poder, hice yo la misma Doña Isabel como su albacea... ante Juan González de Andia, Escribano Público de esta ciudad el día quince del mes de junio del año de mil setecientos setenta y ocho, según se refiere la cláusula de herederos que ha sacado a la letra el citado escribano y dado testimonio a cinco de marzo de este año, que entregamos al presente Escribano para que aquí lo inserte como lo hace que con texto dice así:

Aquí el testimonio de Herederos y aceptando como aceptamos nos las citadas Doña Antonia y Doña Andrea la herencia del referido nuestro padre con beneficio de inventario y no de otra manera y todas tres de un acuerdo y conformidad ...otorgamos que vendemos...a Don Joaquín Valvidares, vecino de esta ciudad, collación de San 
Martín, ... una casa de vecindad nombrada el Corral de Marco Sancho que está al final de la Alameda en la calle que va a la Puerta de la Barqueta en la acera de mano derecha que es el número seis de gobierno que linda por la mano izquierda como se entra por la puerta de la calle con casa del número cinco que son propias de Juan Ruiz, y por la mano derecha, que es el número siete, casa del convento de monjas de Santa María de Gracia de esta ciudad, cuyo corral se compone de diez y siete aposentos bajos y solo tiene vivienda alta encima de la puerta de la calle y tiene dos pozos corrientes y servidumbre y por el centro linda con jardín o Patio del Convento de San Benito de Calatrava y el demás testero hace escuadra y bar (sic) a la calle Rosillas que sale a calle Ciegos $=\ldots \ldots . .$. . (delinde, medidas y tasación de las dos propiedades que componían el solar originalmente y descripción de las condiciones de cesión y venta a Marco Sancho en 1724 entre las que estaban incluidas las de su reedificación. Las peritaciones las realiza el arquitecto Diego Antonio Díaz)... y con efecto, reedificó y labró ambos sitios el dicho Marco Sancho, haciéndola casa de vecindad de esta renta que es en la collación de Omnium Sanctorum y la estuvo poseyendo hasta su fallecimiento que fue el día quince del mes de agosto del año de mil setecientos treinta y tres bajo de un poder de testar que tenía dado a Doña Ángela Díaz Bachiller, su mujer (esta otorgó testamento a la muerte de él y dejó a sus hijos que la poseyeron) hasta que el año de mil setecientos cincuenta y ocho se vendieron con dicha casa de vecindad al referido Don Cayetano de Acosta .... y como tal dueño del corral de esta venta lo estuvo gozando y poseyendo el citado Don Cayetano de Acosta nuestro marido y padre hasta que murió bajo del poder que al principio esta citado y esta inserto testimonio de la cláusula del testamento en virtud ejecutado, y mediante ser los herederos mayores de veinte y cinco años y contestado y sin embargo de haberse principiado autos del cumplimiento del testamento del citado Don Cayețano en cinco de mayo del año de mil setecientos y setenta y ocho.

Marcelino de Avaria, escribano de su Magestad... doy fe que ante dicho señor y por mi presencia se están siguiendo autos sobre el cumplimiento del testamento e inventario y partición de los bienes que quedaron por fin y muerte de Cayetano de Acosta, entre sus hijos y herederos, en los cuales constan tuvieron principio, en cinco de mayo del año pasado de mil setecientos setenta y ocho por petición que presentó Doña Isabel de Amil, viuda y albacea de dicho difunto previniendo y provocando los referidos juicios y pidiendo se le concediese el competente término para presentar el dicho testamento e inventario y habiéndose habidos por provocados los enunciados y juicios y concedido dicho término, se presentó petición en los referidos autos por parte de Andrea de Acosta, mujer legítima de Diego González en la que dijo que siendo una de las hijas y herederas del mencionado Cayetano de Acosta y tratándose por los demás de hacer división convencional del caudal y bienes del dicho su padre como que todos eran mayores de veinte y cinco años y que para ello era precisa la concurrencia de la susodicha la que no podía asistir a ello por ser casada y estar su marido viviendo en casas separadas, con varios motivos que expuso, habiendo ocurrido ante el señor juez eclesiástico a formar autos sobre que hiciese vida 
maridable con la dicha Andrea de Acosta en cuya atención y que estaba detenida la disposición del referido su padre y estrechando los demás herederos a que concurriese a ella para poderlo hacer, concluyó pidiendosele admitiese información de lo expresado y qué fecha se le habilitase para concurrir a la división y partición del caudal prevenido su padre, otorgando el instrumento o instrumentos que fuesen necesarios parecer en juicio y percibir lo que le correspondiese de su legítima a lo que se mandó dar dicha información y evacuada con suficiente número de testigos en su vista por auto de tres de julio del referido año próximo pasado proveído por el señor Don Ignacio Luis de Aguirre que es del dicho Consejo de su Magestad y es Oidor en la repetida Real Audiencia... habilitó a la precedida Andrea de Acosta para que interín la separación del citado su marido, pudiese concurrir a las particiones y demás diligencias que se ofreciesen en la dicha disposición testamentaria del Cayetano de Acosta, su padre, otorgando para sí o con los demás herederos del susodicho los instrumentos que se necesitasen, como también las cartas de pago para la percepción de su legítima..... expresando estar conformes.......... pidieron que se sirviese el Señor Juez de los autos aprobarla interponiendo su autoridad...; cuya cuenta con efecto está firmada con seis firmas y en ella liquiden el caudal partibles entre la viuda y los siete herederos consistentes en sesenta y seis mil cuatrocientos veinte y seis reales y, sacada la mitad de ellos para la predicha viuda, de la otra mitad forman la partición entre los demás interesados, agregando varias partidas que respectivamente tenían recibidas y resulta tocar a cada uno de ellos siete mil seiscientos treinta y dos maravedises de vellón....

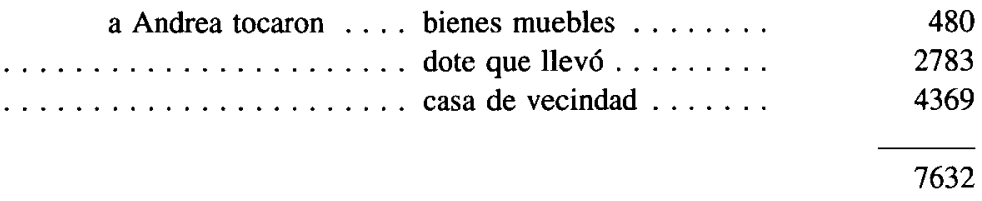

...en Sevilla a 1 de marzo de 1779

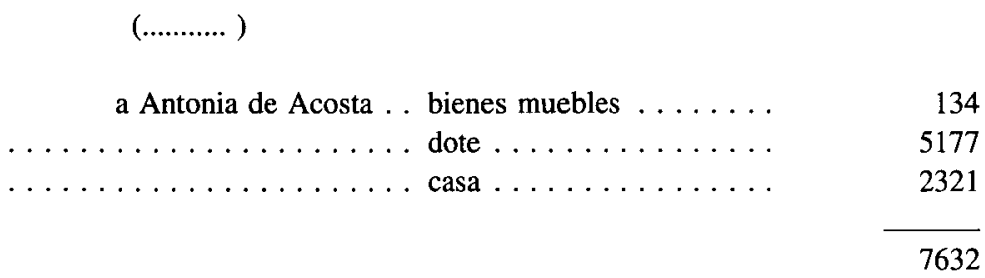

...en Sevilla a dos de marzo de 1779" 


\section{Documento número 9}

Partida de Matrimonio de Juan Bautista Patrone y Maria de los Ángeles Acosta. Archivo Parroquial de San Martín (en San Andrés). Libro de Matrimonios (1785-1807). fol 22.

"En martes treinta días del mes de septiembre de mil setecientos ochenta y ocho años, yo el Beneficiado Don José Hipólito Quiral... desposé y casé por palabras de presente que hicieron legítimo matrimonio a Don Juan Bautista Patrone, natural de Butore (?) Arzobispado de Génova, hijo de Don Jacobo Patrone y de Doña Ángela María Quartin: juntamente con Doña María de los Ángeles Acosta, natural de esta ciudad, hija de Francisco de Acosta y de Felipa de Cáceres, siendo testigos del dicho desposorio Don Francisco de Acosta, Doña Felipa de Cáceres y Don Manuel Calvo, todos vecinos de esta dicha collación. Celebrose este desposorio en la Sacristía de esta dicha iglesia."

Las velaciones se hicieron ese mismo día (fol. 22). 


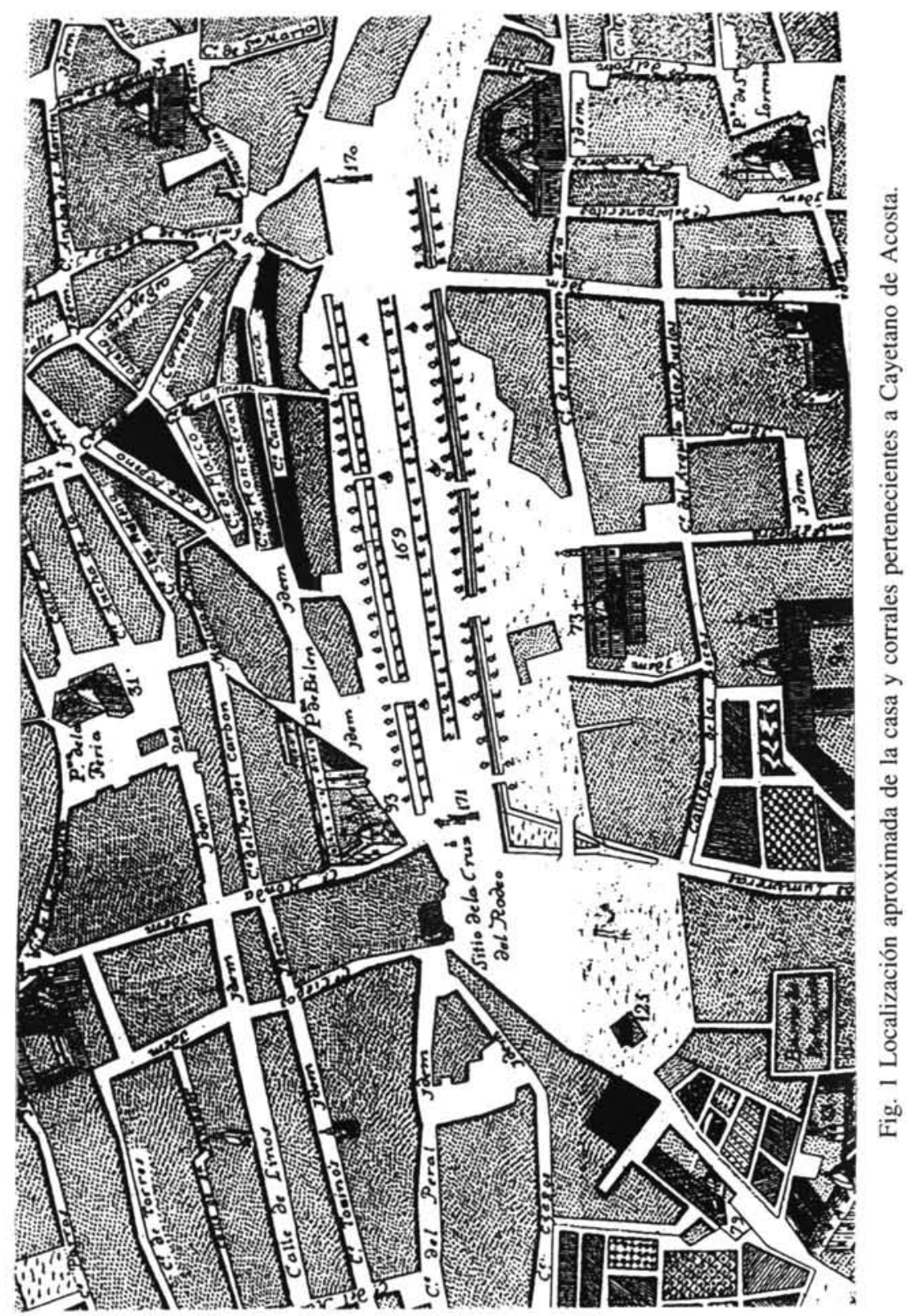




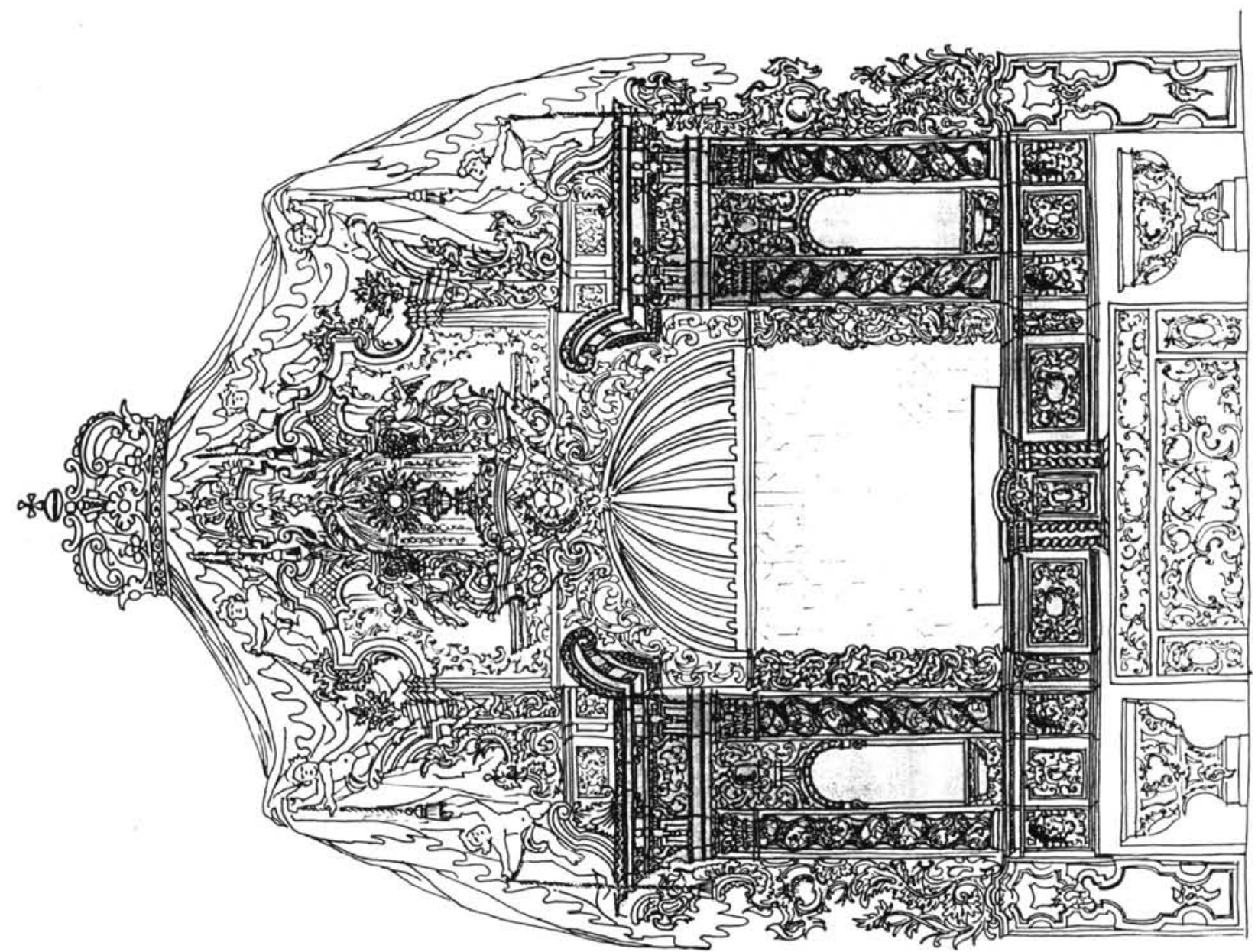




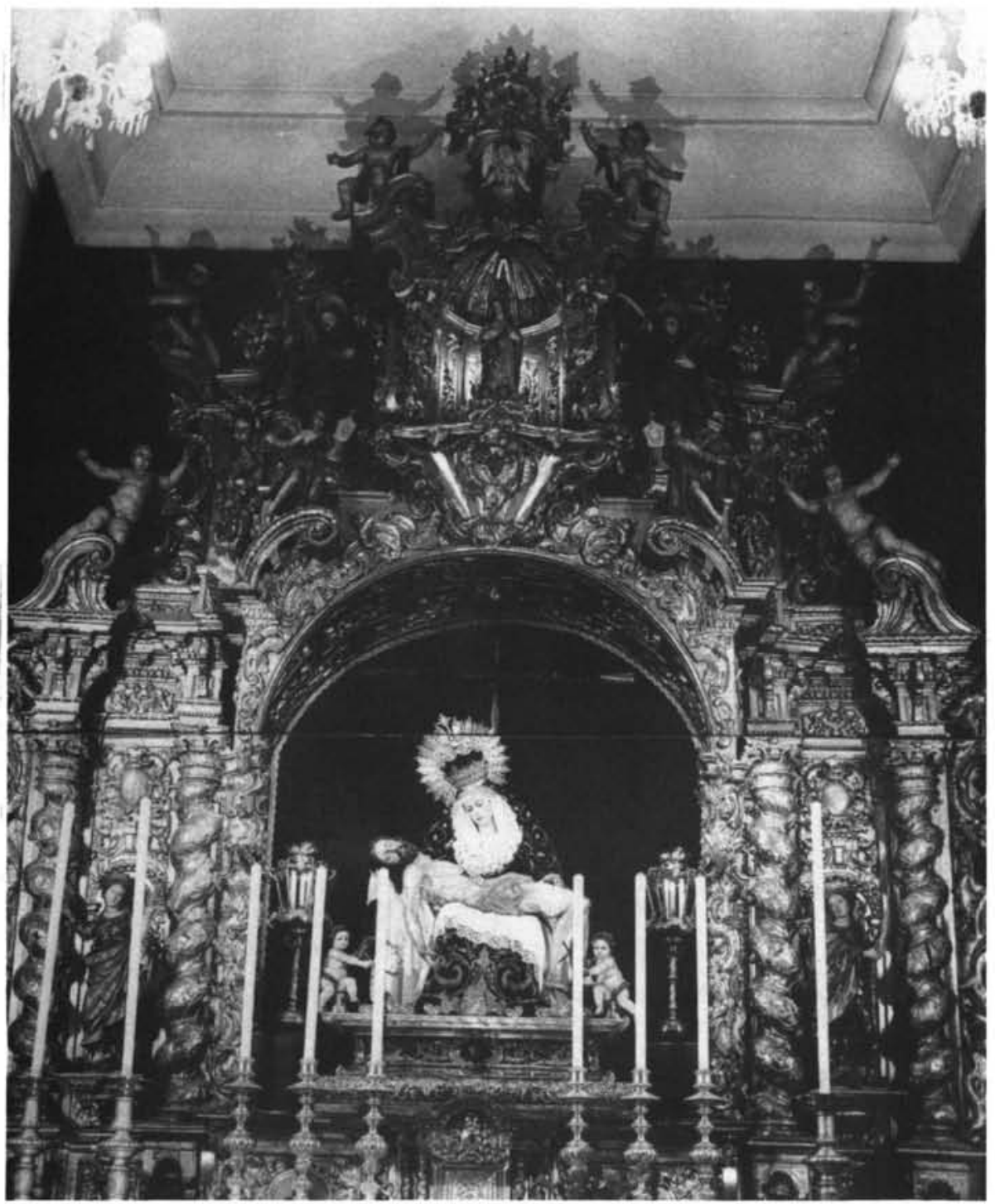

Lám. 2 Retablo de la Hermandad de los Servitas (Sevilla). 


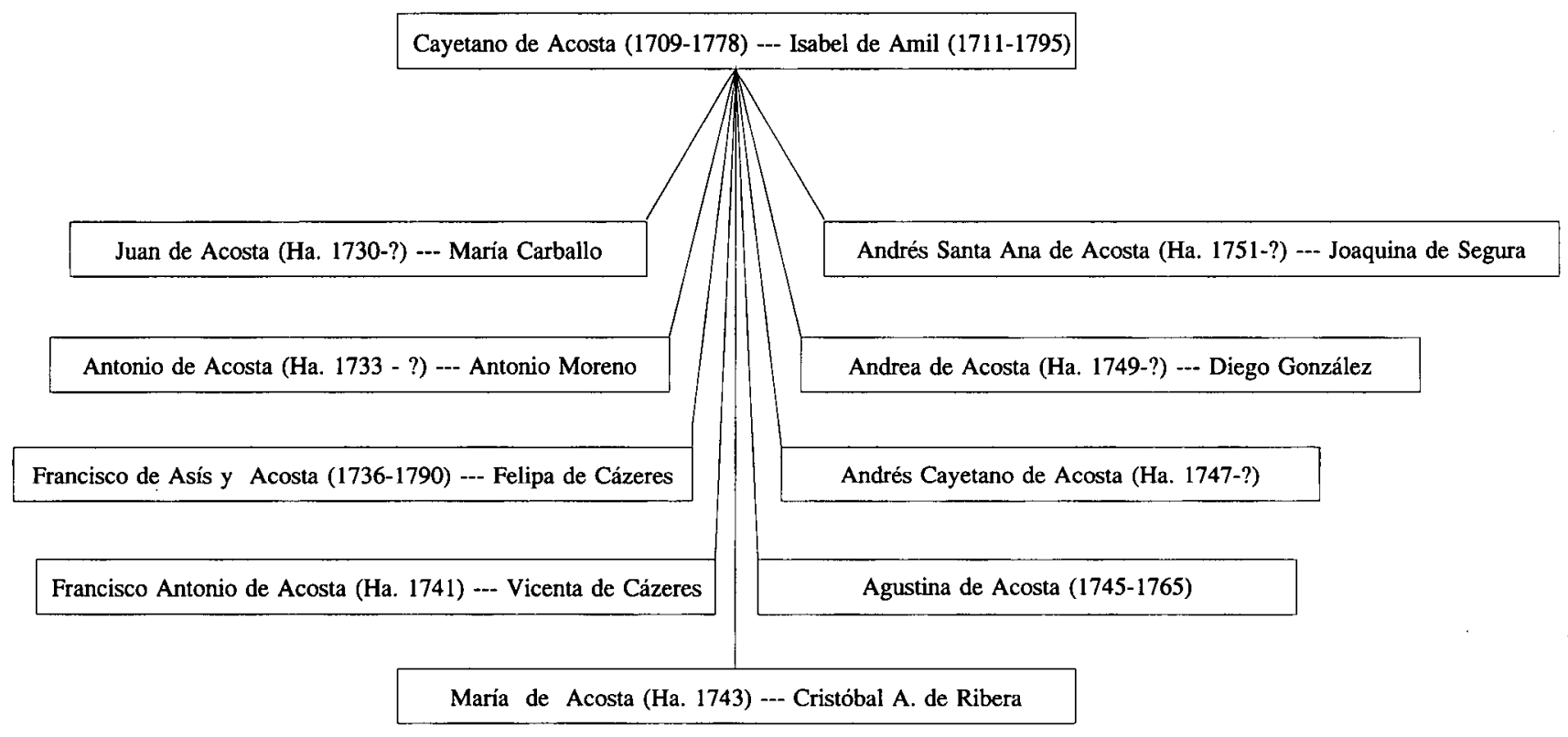

Fig. 3 Diagrama de la familia de Cayetano de Acosta e Isabel de Amil. 


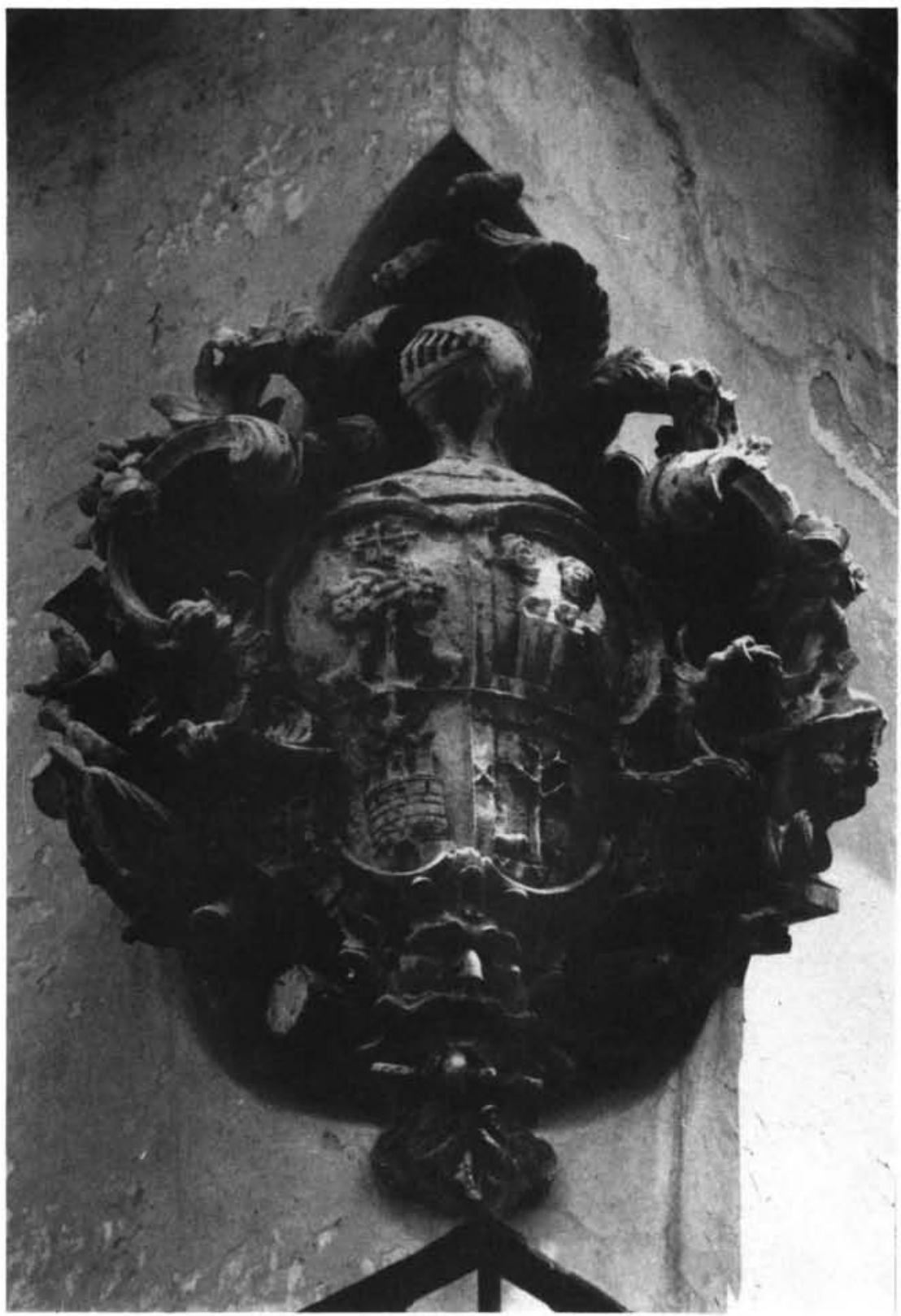

Lám. 1 Escudo heráldico. Palacio de los Pumarejo. Pz. del Pumarejo (Sevilla). 


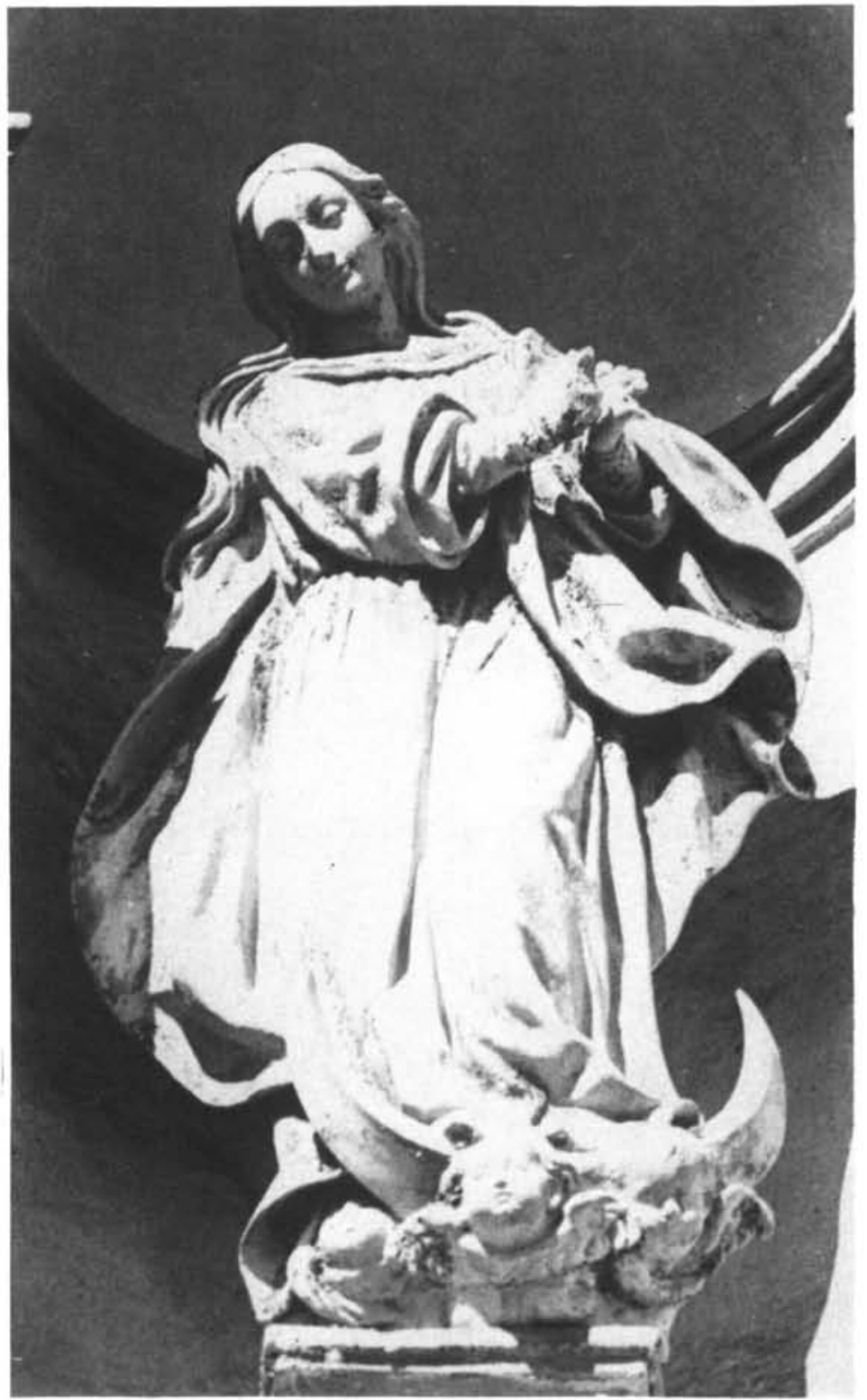

Lám. 3 Inmaculada Concepción. Escuelas Primarias. c/ San Luis (Sevilla). Portada. 


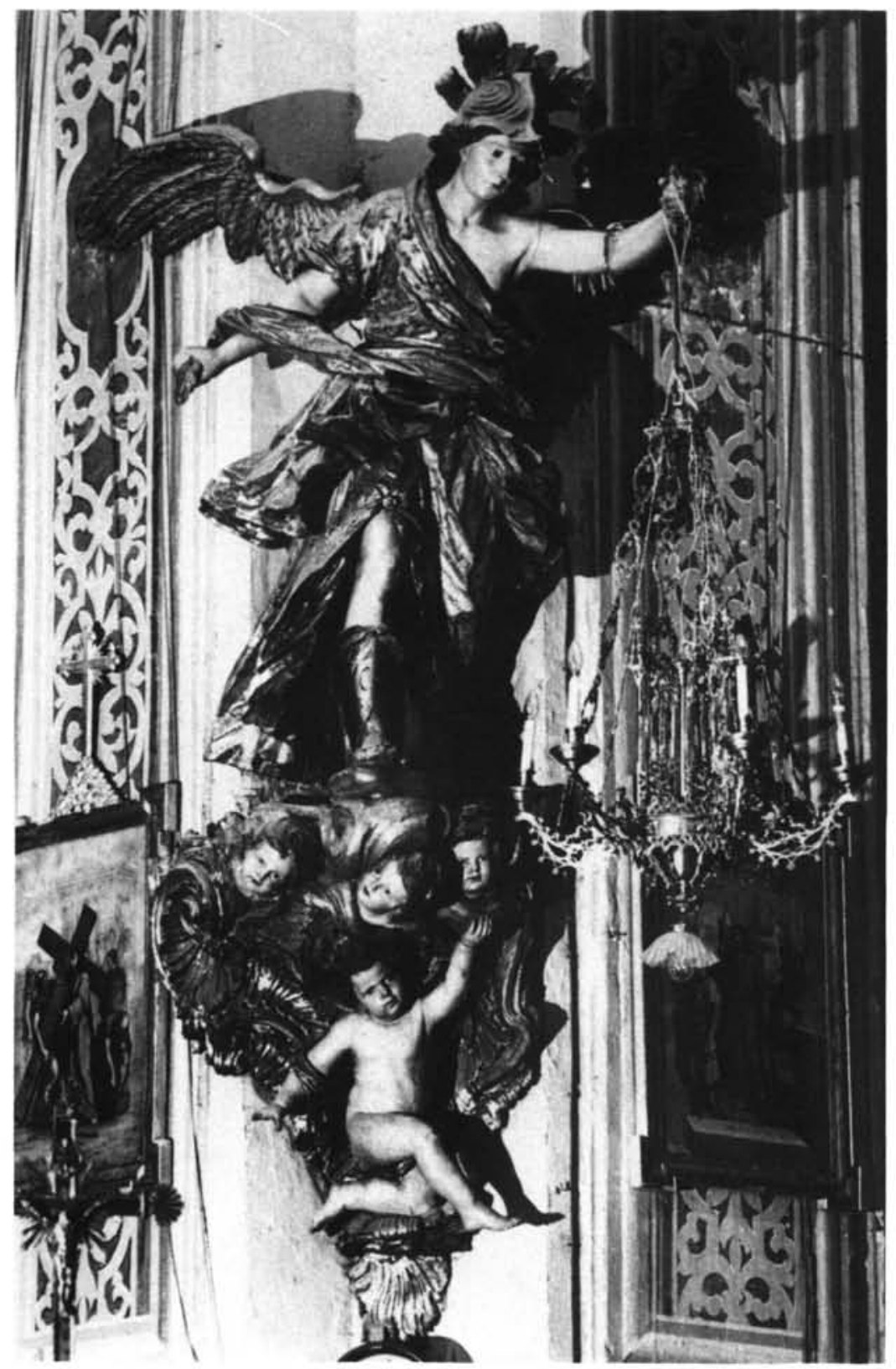

Lám. 4 Ángel Lamparero. Colegio de San Alberto (Sevilla). 